\title{
Exports, jobs, growth! Congressional hearings on US trade agreements
}

\section{Jieun Lee | Iain Osgood (1)}

Department of Political Science, University of Michigan, Ann Arbor, Michigan

\section{Correspondence}

Iain Osgood, Department of Political Science, University of Michigan, Ann Arbor, MI.

Email: iosgood@umich.edu
Who testifies on US trade agreements before Congress and what do they say? We examine the content of Congressional testimony on US trade agreements, and the selection process which determines who testifies in the first place. We find that testimony is systematically tilted toward a sunny view of trade's positive economic effects, while import competition and offshoring are generally downplayed. We argue that trade's supporters strategically frame their motives for supporting trade agreements, and that pro-trade committee chairs' decisions on who testifies further skew testimony away from the distributive consequences of globalization within the United States. Congressional hearings on trade agreements therefore represent a key site where the influence of dominant pro-trade interests is both revealed and reinforced.

\section{1 | INTRODUCTION}

Global economic integration has dramatically changed the US economy in ways both positive and negative over the past decades. The creation of the World Trade Organization and China's accession, along with the passage of free trade agreements with 20 countries, represent key policy developments but also sites for political contestation. Yet in nearly every instance, the United States has actively embraced greater economic openness, only episodically resorting to temporary industry-specific protectionism. ${ }^{1}$ These moves toward ever greater integration have created manifestly positive effects for America's consumers and competitive firms and industries. But the costs of globalization for some US workers, industries, and regions have been steep. ${ }^{2}$ In the wake of the 2016 presidential election and

\footnotetext{
${ }^{1}$ Jensen, Quinn, and Weymouth (2015).

${ }^{2}$ See Owen and Johnston (2017), Autor, Dorn, and Hanson (2013, 2016), Pierce and Schott (2016).
} 
subsequent policy developments, globalization may be in most precarious state since the 1970s, or perhaps even the onset of the Great Depression.

So how did we get here? Recent work on the politics of trade suggests a model of American trade politics with two parts. Politically active producers have been almost overwhelmingly in support of globalization, and have pushed trade agreements aggressively through campaigns of public support and lobbying, matched with contributions. ${ }^{3}$ Opposing producers have been fragmented and ineffectual, or occasionally bought off with strategic carveouts and temporary relief. American voters, on the other hand, have acted as a largely passive but occasionally hostile force, driven primarily by regional decline and affective considerations when they oppose globalization. ${ }^{4}$ Even as their voting focused on more pressing concerns like terror and recession, the damage from globalization-whether perceived or real-accumulated. After the NAFTA debate subsided, this was not readily acknowledged or exploited by politicians until 2016 .

The primary argument of this paper is that Congressional hearings on trade agreements mirror almost perfectly these broader patterns in American trade politics. Party leaders, who are noticeably more supportive of trade than their members, have pushed pro-globalization narratives in support of deeper global integration. Pro-trade interests, especially large exporting and multinational firms and their peak associations, have heavily participated in these debates. Opposing voices have been contained or shut out. Consequently, pro-trade interests have carried the day thanks to careful coordination with the politicians and parties that they generously support. Substantive discussion on negative effects on producers, workers, sectors, and regions have been minimized by leaders eager to reassure members of Congress wary of the hostile attitude toward globalization among their constituents.

Examining Congressional hearings therefore serves several aims. First, hearings are an important site where trade politics plays out, and to which politicians and special interests devote substantial time, a precious political resource. Second, the structure and content of Congressional hearings helps us to understand why trade bills have been so successful, illuminating the role of Congressional leaders and the elite interests which support their parties. Finally, Congressional hearings are a microcosm of the broader debate on globalization in the United States. Elite supporters have carefully structured debate to avoid discussion of negative consequences, and so minimize backlash among the public and their representatives. This approach has wasted opportunities to meaningfully address economic displacement accelerated by globalization, and so may have contributed to the present hostility toward globalization and political and economic elites generally.

In order to make the case that Congressional hearings on trade are fundamentally unbalanced, we examine three types of evidence. We first show that invitations to Congressional hearings — which are mainly controlled by pro-trade committee chairs-are skewed toward likely supporters of trade and globalization. Witness lists tilt heavily toward pro-trade producer interests with relatively little commentary from unions and anti-globalization NGOs. Among producers, firms, and associations from industries that are export-competitive and engage in offshoring-that is, likely supporters of trade-are much more likely to testify.

Expressions of support for, and opposition to, trade agreements in Congressional hearings strongly reflect this pattern of selection. We find that opposition to trade agreements in Congressional hearings is rare, and uncover that one out of three uses of the verb "support" in these hearings are preceded by the word "strongly". Nuanced opinions on trade are in short supply.

We devote the greatest effort to examining the topical content of testimony at Congressional hearings. Testimony is strongly skewed toward the sunny and salable sides of globalization-the exports,

${ }^{3}$ Milner (1988), Kim (2017), Osgood (2017a, 2018).

${ }^{4}$ See Jensen, Quinn, and Weymouth (2017), Mansfield and Mutz (2009), Rho and Tomz (2017), Scheve and Slaughter (2001). 
jobs, and growth of our title. Discussion of US export opportunities account for a full $30 \%$ of all substantive testimony. By comparison, FDI, the sourcing of intermediates, and other aspects of offshoring are grossly under-discussed at these hearings in comparison with their evident importance to American producers. ${ }^{5}$ Much of this unused time is devoted to rhetorical devices designed to persuade wavering members of Congress. We are even able to compare the testimony of firms and associations in Congress to their submissions to the USTR to show that the same actors strategically alter their emphasis in Congressional hearings.

This investigation therefore connects to several literatures in political science. First, we contribute to a long-running debate in American politics about the purpose of Congressional hearings. Are they sites of information exchange; of propaganda; or of constituent service? Focusing on a single issue area, where cleavages over policy change are well understood, allows us to develop a variegated set of empirical implications for each approach. Our results point toward hearings as propaganda aimed at the public, and their persuadable representatives in Congress. Second, our paper connects to the literature on democratic deliberation by showing a site where such dialogue has been lacking. And while we are cautious about claiming direct effects on the recent revival of anti-globalization rhetoric in US politics, it does stand to reason that a richer and more nuanced debate in all public fora might contribute to a more sophisticated discussion on the many benefits, but concentrated costs, of trade integration.

Finally, our work is intended for audiences interested in the process of making international economic policy in the United States. ${ }^{6}$ This is the first study to critically investigate the construction and content of Congressional hearings on trade agreements, and so helps to uncover a relatively unexplored arena for trade policymaking to which policy-makers devote significant time and energy. ${ }^{7} \mathrm{We}$ find that Congressional hearings on trade reflect more general tendencies in American trade politics: a relative elite of firms and select industries fighting for ever greater integration alongside their allies in the leadership of both parties. They confront resistance from certain interest groups, both producers and nonproducers, but are ultimately fighting against hostility from the American voter that is latent but highly potent, if mobilized. Managing and defusing that hostility has been a key strategy, but it may have backfired by avoiding meaningful discussion of ways to mitigate harms caused by globalization's unequal economic consequences.

\section{2 | THE THEORY OF CONGRESSIONAL HEARINGS ON TRADE}

\subsection{Basics of congressional hearings (on trade agreements)}

Scholars of Congress argue that hearings are important (Diermeier \& Feddersen, 2000; Oleszek, 2014). They are a site of dialogue between members of Congress and key constituencies (Truman, 1971). They are venues for oversight of the Executive branch and government agencies (McGrath, 2013). The content of Congressional hearings affects the voting of members of Congress (Andrews \& Edwards, 2004; Burstein \& Hirsh, 2007). The content of hearings often make it into Congressional

\footnotetext{
${ }^{5}$ Milner (1987), Manger (2009).

${ }^{6}$ We join several others in using text analysis to study international political economy, including Krikorian and Szymkowiak (2007), Kim et al. (2016).

${ }^{7}$ Many studies examine Congressional hearings for evidence on the preferences of interest groups in the United States, or as a stage in the creation of trade agreements. See, among others, Schattschneider et al. (1935, Ch. 1), Milner (1988, Ch. 4), Goldstein (1988), O’Halloran (1994, Ch. 6), Irwin (1998), Hiscox (2002, Ch. 4), Manger (2009).
} 
press releases and the news media. The vast amount of staff resources and time put into preparing, attending, participating in, and disseminating committee hearings attest to their significance.

Such hearings take several forms, which are informally classified into legislative, oversight, investigative, and nomination hearings. Legislative hearings focus on the content and effects of prospective bills that are not yet completed, or completed bills that are subject to an upcoming vote. ${ }^{8}$

As Congressional-executive agreements, trade agreements share elements of both treaties and ordinary legislation. On one hand, trade agreements are negotiated by the executive branch. Under the Fast Track or Trade Promotion Authority (TPA) that has been in force for every US trade agreement, the implementing legislation cannot be amended by the Congress. Fast Track rules also set a timeline of at most 90 days for consideration of trade agreements, so committees must move with alacrity to hold hearings. ${ }^{9}$ At the same time, Fast Track/TPA requires implementing legislation for agreements to pass both the House and Senate, but with a majority vote in each chamber. Trade agreements therefore receive committee evaluation in both chambers of the Congress, unlike treaties. A critical role of these hearings is influencing members' votes on negotiated agreements.

Given trade policy's effects on government revenues via tariffs, the main committees covering trade agreements are the House Ways and Means Committee and the Senate Finance Committee. Hearings may take place at the full committee or at the subcommittees which cover international trade. Every trade agreement over the past two decades had hearings under the jurisdiction of these two committees or their subcommittees. Hearings on trade agreements have also taken place in the House Agriculture Committee, the House Energy and Commerce Committee, the House Small Business Committee, and the Senate Committee on Commerce, Science and Transportation.

The decisions on whether and when to schedule hearings are made by the committee chair. Committee staff conduct research for the chair on potential witnesses, who are selected primarily by the chair, and also by other members of the majority and minority parties. Members of the minority are permitted to invite witnesses for some portion of most hearings (Sachs, 2003, 2004).

Committee staff are generally extremely careful in selecting appropriate witnesses. Often witnesses are expected to provide advanced written testimony for the scrutiny of the chair or other members of the committee. They may also be interviewed prior to testifying (Sachs, 2003; pg. 11). Witnesses that end up providing oral testimony will generally only summarize their written testimony, which is then entered into the record in its entirety. Questions for witnesses may be discussed in advance. ${ }^{10}$ Note that members of Congress will often testify themselves; they are usually given precedence and then followed by witnesses from the executive branch, often the USTR or her deputies (Sachs, 2004, pgs. 12, 20). Subsequently, oral testimony is provided by nongovernmental witnesses who may include representatives of industry associations, peak associations, corporations, labor unions, issue advocacy groups, and outside experts (Leyden, 1995). After oral testimony, Congressional hearings on trade often include letters submitted for the record by any of the above who have not testified verbally (Sachs, 2003, pg. 22).

Given the significant power vested in committee chairs to determine the content of hearings, we begin our empirical analysis of Congressional hearings on trade by describing the orientation of committee chairs toward trade. These results are presented in Figure 1. We use a one-dimensional item response theory (IRT) model from Martin, Quinn, and Park (2011) to estimate the ideal points for all

\footnotetext{
${ }^{8}$ See Sachs (2003, pgs. 4-5).

${ }^{9}$ Congressional hearings on trade agreements have generally considered only negotiated agreements that have been introduced into the Congress and referred to committees of jurisdiction as implementing legislation. Prospective agreements may be given some consideration in more general hearings on trade policy, but have never received a devoted hearing for US trade agreements over the past two decades.
}

${ }^{10}$ Sachs $(2003,2004$, pg. 21, pg. 20). 


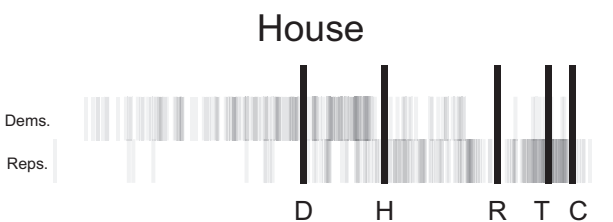

107th

2001

$-2003$
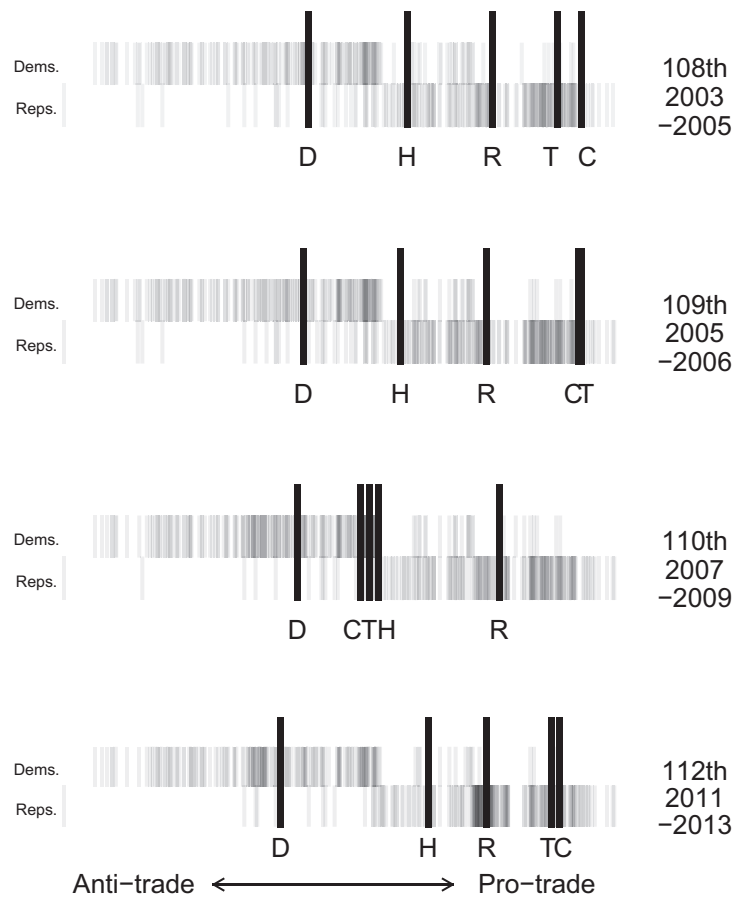

112th

2011

$-2013$

Anti-trade

Pro-trade

Dems.

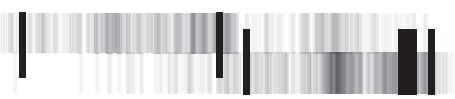

All
comm.

chairs
Senate
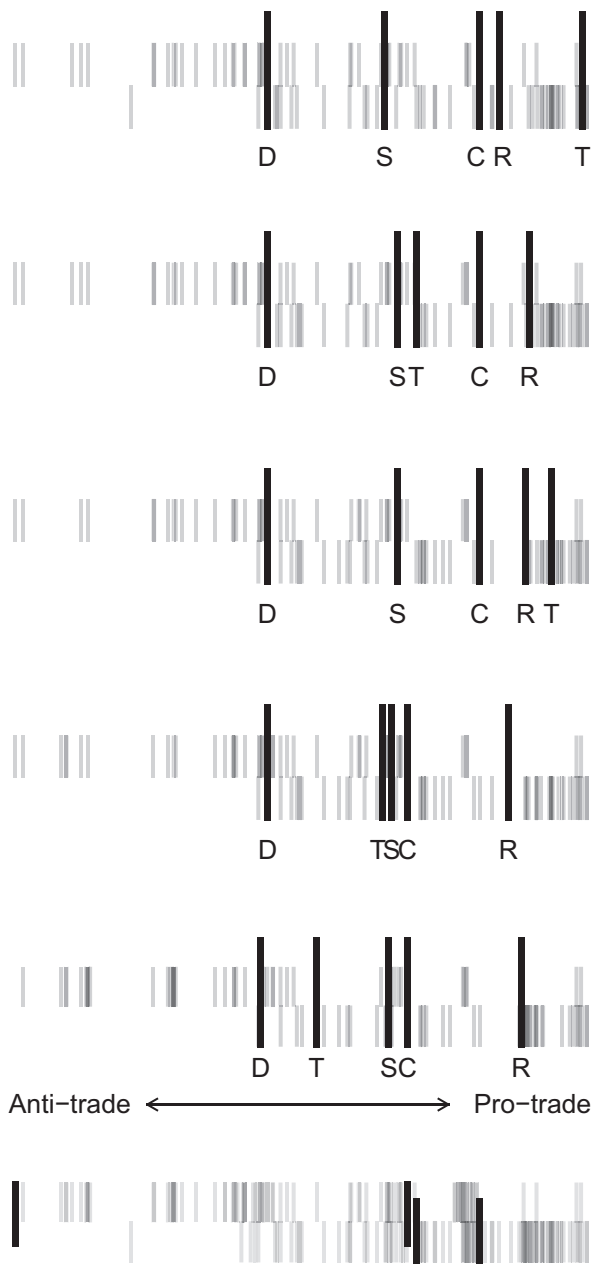

F I G URE 1 Ideal points over trade policy across chamber and party medians, and for relevant committee and subcommittee chairs for Congresses where US PTAs were passed, 2001-2013. H and S represent chamber medians; D and R party medians; and C represents the ideal point of the Ways and Means or Finance Committee chair; T represents the ideal point of the chair of the House Subcommittee on Trade or the Senate Subcommittee on International Trade. Democrats control committees when they have majorities in the House in the 110th Congress and the Senate in the 110th and 112th Congress. Ideal points of committee chairs for all trade hearings are in the bottom row as thick lines, with Democratic chairs starting from the top and Republican chairs starting from the bottom.

members of the House and Senate on major trade legislation from 1995 to 2017. We fit separate models for each chamber using 29 bills in the House and 16 bills in the Senate. ${ }^{11}$

The results from our models are presented in Figure 1. Ideal point estimates for every Congressperson and Senator are presented for Democrats (above) and Republicans (below) across all Congresses. We also highlight several ideal points for comparison: that of the chamber median (represented by $\mathrm{H}$ or $\mathrm{S}$

\footnotetext{
${ }^{11}$ We include all 12 FTAs examined in this paper among these bills for both chambers, and we use members of Congress that voted unanimously for trade-liberalizing legislation to ensure that positive ideal point estimates imply a (relatively) pro-trade orientation, and negative ideal point estimates imply an anti-trade orientation. Using our fitted models, we are able to correctly predict $87.4 \%$ of votes in the House and $89.4 \%$ of votes in the Senate within our sample of trade bills.
} 
for the House and Senate) and of the chamber median among Democrats (D) and among Republicans (R). Finally, we represent with $\mathrm{C}$ the ideal point of the chair of the House Ways and Means or Senate Finance committees. T refers to the ideal point of the relevant trade-focused subcommittee. Note that the Democrats controlled committee chairmanships owing to their majorities in the 110th Congress, and in the Senate only in the 112th Congress. Ideal points of all committee chairs who held hearings on trade agreements are presented at the bottom.

We emphasize several facts. First, the median Republican is noticeably more pro-trade than the median Democrat, but there is substantial overlap in the distributions for the two parties. Trade is not subject to the party-line polarization that characterizes Congressional voting generally. This lack of strict party discipline, especially in the House, means that trade bills often require bipartisanship. Second, committee chairs are generally quite pro-trade. ${ }^{12}$ Indeed, with only a few exceptions, the relevant committee chairs are more pro-trade than both their chamber and party medians. Given the prominent role of committee chairs in constructing hearings on trade agreements, this naturally suggests that hearings might skew in a pro-trade direction.

\subsection{Learning, propaganda, or constituent service: What is the purpose of hearings?}

A rich literature in political science examines the purpose of Congressional hearings. Taking the justifications from Congress on their face, an early claim was that legislative hearings are fundamentally about a holistic examination of issues designed to improve legislation through the transmission of information. This may be to defend the public interest against "special interests" or to communicate those same special interests' desires to the Congress (Huitt, 1954; Truman, 1971). One early scholar of committees proposed that "the committee play[s] principally the part of a legislative court, listening to the evidence brought before it by interested parties..."13 While many critiques of the view that hearings are sites of information exchange and learning have emerged, it is supported in recent work on Congressional hearings (Burstein \& Hirsh, 2007).

A contrary perspective contends that hearings are a highly controlled and stylized method by which members of Congress communicate to key constituencies, whether narrow interest groups, broader publics, or fellow members of Congress. Truman (1971, 372-377) succinctly characterizes this viewpoint as the committee as "propaganda channel". The careful construction of lists of testifying witnesses by committee chairpersons, and the vetting and even rehearsal of testimonies, lend credence to this perspective. In this view, committee chairs with a particular position seek out sympathetic witnesses to provide persuasive testimony designed to target key constituencies. A related claim is that hearings are designed by chairs to persuade other members of Congress, whether through rhetoric or by demonstrating that interest groups have strongly held positions pointing in a particular direction. ${ }^{14}$

\footnotetext{
${ }^{12}$ This observation connects to the literature on committee members and leaders as "preference outliers". See, for example, Shepsle (1986), Shepsle and Weingast (1987), Krehbiel (1990), Adler and Lapinski (1997). The strongly pro-trade preferences of chairs of committees governing trade may therefore reflect their own selection into those committees, due to the high salience of the issue. Chairs' pro-trade stances may also reflect the interests of their parties (especially the Republican party), which are highly dependent on corporate contributions for their fundraising. In this view, parties appoint pro-trade chairs to ensure that the interests of a key constituency, very large corporations, are given pride of place in committee activities.

${ }^{13}$ See Chamberlain (1936, pg. 79) quoted in Huitt (1954). A related claim is that committee hearings are sites of deliberative democracy, where actors can learn facts about the world and about one another's interests, as part of an ongoing process of legitimate policymaking (Esterling, 2011; Gutmann \& Thompson, 1998).

${ }^{14}$ Alternatively, committee hearings may be designed to communicate the positions of committee members to the floor, as in a rich formal literature. See Gilligan and Krehbiel (1987), Diermeier and Feddersen (2000).
} 
A distinct critique of "learning-by-hearings" argues that, rather than communicating to constituencies or one another, committees perform constituent service with hearings. Politicians have many demands on their time. Holding a lengthy hearing and listening to hours of testimony is a costly signal of the importance that politicians place on the interests of key constituencies. For example, inviting corporate stakeholders allows a member of Congress to show that the voice of those groups (who may also be giving contributions and other political support) are important. In return, the constituents get an opportunity for prestige or influence (Adler \& Lapinski, 1997).

Each of these approaches-hearings as learning, propaganda, or constituent service-have implications for all of the different facets of legislative hearings. We highlight three here. First, who gets invited to testify? For example, if hearings are about learning, then we would expect a broad slate of interests to be invited representing a diversity of viewpoints. If, however, hearings are about propaganda, then we expect a skewed and limited set of testifiers whose interests align with the committee's leadership. The second question is what is the relative rate of support and opposition to the proposed legislation among groups invited to testify? If committee chairs are proposing or supporting some particular piece of legislation, then a hearing that was essentially propaganda would target only supportive interest groups to testify. Finally, what do witnesses say? If hearings are about learning, we might expect testimony to be realistic, truthful, and nuanced. If hearings are propaganda, we would expect the content of testimony to be skewed, with arguments strategically chosen to maximize persuasion of targeted audiences.

\section{3 | Trade and globalization in Congressional hearings, and in real life}

Trade and globalization have recently come in for intensified contestation. Surveying the literature on the effects of trade and foreign investment, several themes emerge about the recent decades of globalization. We summarize them here as: consumption, export opportunities and import competition, offshoring, globalization of the supply chain, the growing scope of global institutions, global imbalances, deindustrialization, and stagnation. These themes provide the backdrop for the hearings we examine, and also set a subjective and informal baseline against which the thematic content of hearings can be judged.

The first of these is the enormous growth in world trade, and concomitant gains for consumers (Baker, 2003, 2005). In the United States, globalization has brought a bounty of consumer choice in terms of cost and variety. Much of this plenitude owes to two facets of globalization. First, the United States is much more open to imported goods made by foreign-owned firms. Imports as a percentage of US GDP rose from around 10\% in 1980 to over $15 \%$ in 2015. US trade partners are also much more open to trade, and US exports have grown from $9.8 \%$ to $12.6 \%$ over the same span. Second is the rise of offshore production and multinational supply chains. ${ }^{15}$ Many US producers have moved production overseas in order to lower labor costs or increase efficiency through proximity to better-developed foreign supply chains (Baccini, Pinto, \& Weymouth, 2017). Other firms have developed extensive multinational supply chains, sourcing intermediates cheaply abroad for final assembly back in the United States (Acharya, 2015; Gawande, Krishna, \& Olarreaga, 2012).

As trade has expanded, globalization has generated large trade imbalances (Chinn \& Frieden, 2011, Ch. 2). The United States has run a trade deficit since 1971. These deficits, along with the specialization unleashed by the operation of comparative advantage, are one cause of the startling decline in US manufacturing as a share of employment (Pierce \& Schott, 2016; Sachs, Shatz, Deardorff, \& Hall, 1994). Several studies have argued that trade with low-wage countries, primarily China, has

${ }^{15}$ See Johns and Wellhausen (2016), Manger (2012), Chase (2009). 
reduced the wages of American workers in exposed industries, and perhaps heightened inequality (Autor et al., 2013, 2016). The offshoring of jobs by US firms has also proven particularly politically salient (Margalit, 2011; Owen \& Johnston, 2017). The global institutions that manage international trade-especially the WTO but also trade agreements-have therefore come in for heavy criticism. Some of this comes from unions, and anti-trade firms and industries. But the recent era of global institutionalization has vastly expanded the reach of trade agreement in areas of state sovereignty and regulation, activating a wide array of pro-development and anti-corporate groups.

In sum, globalization (and the trade agreements that have facilitated it) has exerted enormous influence on the US economy and the workers in it. Modern global institutions also have big effects on foreign countries and workers, which have activated many interest groups in the United States that are key constituencies to members of Congress. Some of the effects of global economic integration are highly positive or neutral, while others are negative, at least for a portion of society. Do Congressional hearings on trade agreements reflect these multifarious effects of trade, including trade's positive and negative impacts? Or, do Congressional hearings present a biased or simply incomplete portrait of the effects of trade and globalization?

The three approaches to understanding the purpose of Congressional hearings described above suggest distinct theoretical expectations on the answers to these questions. We consider each approach in order, emphasizing our three main questions from above: Who gets invited? Are they supportive? And, what do they say? We summarize our theoretical expectations in Table 1.

T A B L E 1 Expectations across three theoretical perspectives on Congressional hearings

\begin{tabular}{|c|c|c|c|}
\hline $\begin{array}{l}\text { Theory of } \\
\text { hearings }\end{array}$ & Learning and info. exchange & $\begin{array}{l}\text { Pro-globalization } \\
\text { propaganda }\end{array}$ & Constituent service \\
\hline \multicolumn{4}{|c|}{ Characteristics of invitees } \\
\hline $\begin{array}{l}\text { Among all } \\
\text { invitees }\end{array}$ & $\begin{array}{l}\text { All interested stakeholders } \\
\text { should be represented }\end{array}$ & $\begin{array}{l}\text { Pro-globalization stakehold- } \\
\text { ers only, mainly producers }\end{array}$ & $\begin{array}{l}\text { Producers and unions that } \\
\text { are politically influential }\end{array}$ \\
\hline $\begin{array}{l}\text { Among } \\
\text { producers } \\
\text { specifically }\end{array}$ & $\begin{array}{l}\text { Import- and export-competing } \\
\text { firms and associations, and with } \\
\text { interests in offshoring, } \\
\text { outsourcing, and regulation }\end{array}$ & $\begin{array}{l}\text { Mainly export-competing } \\
\text { firms and associations }\end{array}$ & $\begin{array}{l}\text { Mainly politically } \\
\text { powerful producers }\end{array}$ \\
\hline \multicolumn{4}{|l|}{ Positions } \\
\hline $\begin{array}{l}\text { Expressed } \\
\text { positions of } \\
\text { testifiers }\end{array}$ & $\begin{array}{l}\text { Mixture of support, opposition, } \\
\text { and nuanced positions }\end{array}$ & $\begin{array}{l}\text { Mainly unambiguous } \\
\text { support }\end{array}$ & $\begin{array}{l}\text { Mixture of positions } \\
\text { reflects political } \\
\text { influence }\end{array}$ \\
\hline \multicolumn{4}{|c|}{ Topical content of hearings } \\
\hline $\begin{array}{l}\text { Overall content } \\
\text { of topics }\end{array}$ & $\begin{array}{l}\text { Wide-ranging coverage of the } \\
\text { issues at stake, with both } \\
\text { positive and negative valence }\end{array}$ & $\begin{array}{l}\text { Coverage of positive facets: } \\
\text { exports, jobs, growth, } \\
\text { development, competitive } \\
\text { liberalization }\end{array}$ & $\begin{array}{l}\text { Wide-ranging coverage of } \\
\text { the issues at stake }\end{array}$ \\
\hline $\begin{array}{l}\text { Truthfulness of } \\
\text { testimony } \\
\text { among } \\
\text { producers }\end{array}$ & $\begin{array}{l}\text { Testimony reflects the industrial } \\
\text { characteristics of testifiers, in } \\
\text { direction and proportion }\end{array}$ & $\begin{array}{l}\text { Testimony is orthogonal to } \\
\text { industrial characteristics, } \\
\text { or is out of proportion to } \\
\text { the importance of issues }\end{array}$ & $\begin{array}{l}\text { Testimony reflects the } \\
\text { industrial characteristics } \\
\text { of testifiers, in direction } \\
\text { and proportion }\end{array}$ \\
\hline $\begin{array}{l}\text { Hearings versus } \\
\text { submissions }\end{array}$ & Similar topical content & $\begin{array}{l}\text { Submissions should have } \\
\text { more discussion of } \\
\text { sensitive issues }\end{array}$ & Similar topical content \\
\hline
\end{tabular}


If Congressional hearings on trade are unbiased fact-finding missions, we expect a diverse array of interests to be invited from among producers, workers, NGOs, and consumer groups. Among producers, we expect that firms and associations from industries with different stakes in globalization will be invited-some export-competing, some import-competing, some offshoring. Since trade has distributive implications between and within industries, we also expect at least some balance in terms of support for, or opposition to, trade among producers. Finally, the content of testimony should be holistic, covering the range of issues described above, including trade, foreign investment, sourcing, and the important regulatory aspects of modern trade agreements.

If hearings on trade agreements are propaganda, we will see very different patterns. We highlight that a bias could go in several directions but we describe a pro-globalization bias for concision. Under this model, invitees to hearings should be drawn from groups that are likely to support globalization. Witnesses should express unequivocal support for the trade agreement, and globalization generally. As for content, hearings should focus mainly on the happier sides of globalization (like exports, jobs, and growth) while ignoring globalization's contested elements (offshoring, job loss, lost sovereignty). We would also expect that producers testifying in this public setting would reframe their expressed interests compared to private settings.

The third theoretical possibility-that hearings are essentially constituent service-generates a distinct pattern of empirical expectations. We expect that invitations to testify will be generally associated with the political importance of groups, not their representativeness or attitudes, as above. We also expect that those invitees would be a mixture of supporting and opposing on the legislation, at least to the extent that both sides were politically important to chairpersons in charge of the committee. Finally, we would expect the content of such hearings to be mostly honest; that is, firm and associations will be happy to discuss foreign investment, offshore-outsourcing, regulatory demands, and other features of their authentic interests in trade policy.

One final point: it is likely that pro-trade firms are also politically influential firms (e.g., because of a link between firm size and pro-trade attitudes). Pro-trade firms may also have more intense preferences over trade agreements due to the concentration of gains from globalization in their hands. For these reasons, distinguishing hearings as either "pro-globalization propaganda" or "constituent service" using only the characteristics and positions of invitees may be difficult, and the two theories may to some extent coexist. However, these theories generate distinct empirical implications on the topical content of hearings, because the purposes of propaganda require disguising any unhappy sides of globalization. Examining topical content is therefore critical for identifying a motive of propaganda.

\section{3 | THE DATA}

Our data begin with 34 unique Congressional hearings on US trade agreements, from 2001 to the present. Some of these hearings cover multiple trade agreements. We break up the elements of these hearings that cover the separate agreements in order to match testimonies to specific trade partners. ${ }^{16}$ Once hearings are broken up by trade agreement, we have a total of 48 agreement-hearings, and 874 testimonies. We only consider hearings that were primarily focused on the economic implications of agreements; we do not examine in this paper hearings focused specifically on the diplomatic relations among states, which have occurred occasionally. ${ }^{17}$

\footnotetext{
${ }^{16}$ Elements of the testimony that cover all of the included agreements in a generic way are included in all of the country-specific testimonies.

${ }^{17} \mathrm{We}$ also do not examine in this paper a special issue hearing focus on financial liberalization in Singapore.
} 
Hearings and testimonies are assigned metadata on basic features of hearings and witnesses. For the hearings, we record the name, date, chamber, and title of the hearing, as well as characteristics of the chair. For the testimonies, we include data on the witness testifying; the name and type of group that the witness is representing (if relevant); the sector and six-digit NAICS industries if a corporation or trade association is testifying; and a variable indicating the position (for, against, no position or other) expressed by the witness toward the agreement. We record if the testimony was presented orally or through a letter for the record.

Our greatest effort focused on hand-coding the topical content of the hearings at the level of the paragraph. We used a set of predetermined paragraph topic codes built off of our initial examination of the documents, and added codes where we encountered unanticipated topical content, ending up with 56 total codes that we used in the project. Supporting Information Table S2 lists our topic codes. A single paragraph may have multiple topic codes. In these cases, we equally divide up the paragraph for allocation to topic counts. For example, a paragraph with three topics contributes one-third of a paragraph to the count for each of the topics covered. We coded 23,747 paragraphs overall.

Some tags are not informative, for example, salutations and introductions ("Intro") or nonrelevant material like expressions of support for unrelated trade policy issues ("Nonrel"). Some of the topics are politically meaningful but not about the substantive features of the agreement, for example, comments on the timetable for completion of the agreement ("Timetable") or about the procedures for gathering stakeholder feedback ("Process"). The remaining topics are all about the substantive content of the agreement or likely effects of the agreement, and are categorized into five broad sets: ordinary export opportunities and import competition; foreign sourcing and international investment; expanded trade agenda items like SPS measures, TBTs, rules of origin, and labor standards; effects of the agreement on jobs, growth, and consumers, whether at home or abroad; and broader strategic issues like the partner countries being US allies or the impacts of the agreement on development or democratization (Gowa \& Mansfield, 1993; Mansfield \& Bronson, 1997; Mansfield, Milner, \& Rosendorff, 2002).

Our analysis of the content of hearings on trade agreements focuses on substantive content. We therefore exclude from the denominator the topics that we refer to as "intro", "outro" (insubstantive concluding statements, and thank yous), "nonrel", and "position" (where the testifier expresses sentiment like "We support agreement X"). We also exclude the categories for "process", "timetable", "mobilization" (comments on the organization of interest groups over the agreement), and "revisions" (a tag for discussion of previous or current revisions to the agreement). These statements are quite common but mainly pro forma courtesies (e.g., commending the USTR for a positive process gathering stakeholder feedback, or describing details of the process of communicating with the USTR or Congress).

Several of our testable empirical implications require us to match testifiers who are producers to the trade characteristics of their industries. To do this, we use our own codings of the six-digit North American Industrial Classification System (NAICS) industries of the testifying firms or trade associations (peak associations are too broad to be matched to an industry). We measure for each firm or association their industry's exports to the trade agreement partner(s); their imports (not arising from related parties) from the partner(s); their related-party imports (a proxy for vertical FDI); and a measure of imported intermediate goods. These data come from the Census Bureau's NAICS Related-Party Trade data. Working at the industry level allows us to examine firms and associations jointly, but we investigate also firm-level implications and data in the Supporting Information Appendix S2.

Our discussion of hearings as 'constituent service' requires suitable proxies for the political influence of constituencies. We do this in two ways, acknowledging that there are many plausible strategies. First, we measure the total political action committee (PAC) contributions of the firms and 
associations that make up each six-digit NAICS industry to the committee chair. ${ }^{18}$ We refer to this variable as Chair's contributions. Second, we examine the number of establishments in every six-digit industry in the relevant chair's state. We refer to this variable as Chair's establishments. We employ a wide range of methods to present our data below, most of which are descriptive. We justify any parametric models or graphical summaries as they arise.

\section{4 | FINDINGS ON INVITATIONS AND SUPPORT}

\subsection{Who testifies at Congressional hearings?}

Members of Congress and representatives from the executive branch are $18.9 \%$ and $6.1 \%$ of all witnesses, respectively. These members of Congress are often the committee chair and ranking minority member. ${ }^{19}$ Of the 53 witnesses from the executive branch, all but 11 come from the Office of the United States Trade Representative, and are naturally strongly in support of the treaties they have negotiated. Among nongovernmental witnesses, an overwhelming $82.6 \%$ of witnesses are producers-whether corporations, trade associations, or peak associations. Interest organizations, labor unions, and experts represent $9.2 \%, 4.3 \%$, and 3.2\% of all nongovernmental witnesses, respectively. This lack of representation by issue groups and unions is a first data point that the composition of hearings tilts toward globalization advocates (Albert, 2013).

Which producers are represented in Congressional hearings? To answer this, we consider three leading explanations of support for global trade agreements among firms. We check if firms and associations representing industries that export more (and face less import competition) are more likely to be represented in hearings. We investigate whether industries with more related-party imports (a proxy for vertical mulitnationalization by US firms, i.e., the offshore production of final products) are better represented. Finally, we examine whether industries that are likely to be more dependent on imported inputs are more likely to testify.

To assess these links, we build a panel of producer representation at Congressional hearings on our 48 hearings at the six-digit NAICS industry level. The outcome variable is a dichotomous measure of whether a six-digit industry was represented by a firm or trade association at the hearing in question. We use a linear probability model so that we can include hearing and industry fixed effects. ${ }^{20}$ The hearing fixed effects (which also act as trade partner and committee fixed effects) are key because the length and breadth of hearings is likely to vary across committees and trade partners for reasons which are unrelated, but potentially correlated, with the composition of trade flows. ${ }^{21} \mathrm{We}$ are only able to examine trade variables for goods-producing industries as fine-grained trade data are unavailable for the services sector. Our sample size is therefore 48 hearings $\times 404$ industries $=19,392$ observations.

\footnotetext{
${ }^{18}$ Contributions data are provided by the Center for Responsive Politics. Concordancing from CRP industries to six-digit NAICS industries was done by the authors. Contributions from CRP codes which map to multiple six-digit industries are allocated to those industries in proportion to industry sales.

${ }^{19}$ The CAFTA-DR hearings saw an exceptional number of brief submitted testimonies by members of Congress, many of whom expressed concern about the deal's consequences for the sugar and textile industries. These four hearings out of 48 account for $22.2 \%$ of all testimony by members of Congress.

${ }^{20}$ We employ three-digit industry fixed effects in the main text and six-digit industry fixed effects in the Supporting Information Appendix S2. The results are entirely robust to the inclusion of the six-digit fixed effects.

${ }^{21}$ The outcome is multiplied by 100 to avoid excessive zeroes in the table. All substantive effects are interpreted in the main text as percentage changes in the probability of being represented at a hearing. For example, an increase of the probability of testifying from 0.5 to 0.75 is a $50 \%$ increase in the probability.
} 
All trade data are averages over the years 2005 to 2009 and we check in the Supporting Information Appendix S2 all our results using averages from 2010 to 2014.

The first three columns in the top half of Table 2 examine the conditional correlations between the trade variables and representation at hearings, sequentially introducing the fixed effects. ${ }^{22} \mathrm{We}$ find that industries which export more are more likely to be represented in hearings on trade agreements. Raising the quantity of exports to some trade partner from its 25 th to 75 th percentile in the data raises the probability that an industry will be represented at a given hearing by $18.9 \%{ }^{23}$ Industries with more related-party imports and imported inputs are also more likely to be represented. These correlations are large and quite consistent across specifications. For example, moving related-party imports from their 25th to their 75th percentile increases the probability of representation at a hearing for an industry by $35.0 \%$. A similar increase in imported intermediates is expected to increase the probability of representation by $28.8 \% .^{24}$ The model with trade variables easily rejects a null model absent industry trade flows as shown in the likelihood ratio tests.

The recent trade politics literature emphasizes that in most industries a small number of very large firms dominate almost all exporting, importing, and foreign investment (Kim \& Osgood, 2019). ${ }^{25}$ This heterogeneity among firms implies that the most productive (and usually largest) firms in an industry are likely to be the strongest advocates for trade. This approach generates a firm-level implication which complements out industry-centered findings from above: we would expect larger firms and firms with foreign affiliates to be more likely to be invited to testify at Congress, since these are the firms that strongly support globalization. In the Supporting Information Appendix S2, we show using the firm-level data that precisely these patterns hold. ${ }^{26}$

Firms and industries which heavily export, import, and produce abroad are likely to be supportive of trade agreements. So if committee leaders are putting together hearings skewed toward positive views of trade agreements, such a choice makes sense. These results are therefore consistent with a model of hearings as 'pro-globalization propaganda' generated by the close coordination of committee chairs and pro-trade witnesses. However, offshoring is hardly a sunny side of globalization from the perspective of American voters and workers (and the wavering members of Congress that represent their interests). So the overrepresentation of industries that offshore production could undermine efforts at pro-globalization "cheerleading" if offshoring is frankly acknowledged in the hearings. We therefore carefully examine below the extent to which witnesses actually discuss the benefits (or harms) of offshoring in our content analysis of hearings.

In columns 4-6 of Table 2, we investigate our primary mechanism-that pro-trade committee chairs are managing the content of hearings through selective invitations. To do so, we interact each

\footnotetext{
${ }^{22}$ The sample size drops with industry fixed effects because some three-digit industries have no representation ever.

${ }^{23}$ This estimate employs Model 1, and the 95\% confidence interval is (11.0, 28.1). Industries that import more are somewhat less likely to be represented although this relationship is substantively small and not significant. The insignificance of the ln Imports coefficient is not entirely consistent with our theory, although we note that the sign is as we would expect.

${ }^{24} 95 \%$ confidence interval's for these estimates are $(14.3,61.4)$ and $(16.0,43.7)$, respectively.

${ }^{25}$ These patterns are especially likely in industries where product differentiation is great (Kim, 2017; Madeira, 2016; Osgood, 2016), and where opportunities for global sourcing and foreign production are high (Blanchard \& Matschke, 2015; Jensen et al., 2015; Osgood, 2017b).

${ }^{26} \mathrm{We}$ also examine whether firms or industry associations provide testimony, inspired by the literature on firms, associations, and lobbying [e.g., Bombardini and Trebbi (2012)]. We suspect that where import competition and global sourcing are present, that firms might be likely to testify than associations because industries will not share a united position. We find a consistent pattern that import competition leads firms to testify rather than associations, some evidence that global sourcing leads firms to testify over associations.
} 
T A B LE 2 LPM for inclusion of testimony in Congressional hearings

\begin{tabular}{|c|c|c|c|c|c|c|}
\hline Model & 1 & 2 & 3 & 4 & 5 & 6 \\
\hline \multicolumn{7}{|c|}{ Results without political influence variables } \\
\hline \multirow[t]{2}{*}{ In Exports } & $0.439 * * *$ & $0.358 * * *$ & $0.176^{+}$ & -0.371 & -0.310 & $-0.579 *$ \\
\hline & $(0.088)$ & $(0.086)$ & $(0.103)$ & $(0.257)$ & $(0.252)$ & $(0.285)$ \\
\hline \multirow[t]{2}{*}{ In Imports } & -0.051 & -0.087 & $-0.211^{+}$ & 0.486 & 0.401 & 0.486 \\
\hline & $(0.108)$ & $(0.107)$ & $(0.121)$ & $(0.316)$ & $(0.311)$ & $(0.347)$ \\
\hline \multirow{2}{*}{$\begin{array}{l}\text { In Rel party } \\
\text { imports }\end{array}$} & $0.363 * * *$ & $0.371 * * *$ & $0.288 * *$ & -0.126 & -0.016 & -0.143 \\
\hline & $(0.100)$ & $(0.099)$ & $(0.110)$ & $(0.284)$ & $(0.282)$ & $(0.310)$ \\
\hline \multirow{2}{*}{$\begin{array}{l}\text { In Imported } \\
\text { inputs }\end{array}$} & $0.713 * * *$ & $1.301 * * *$ & $2.518 * * *$ & 0.363 & -0.208 & $1.236^{+}$ \\
\hline & $(0.152)$ & $(0.210)$ & $(0.271)$ & $(0.437)$ & $(0.620)$ & $(0.720)$ \\
\hline \multirow{2}{*}{$\begin{array}{l}\text { Chair's ideal } \\
\text { point }\end{array}$} & & & & -0.541 & & \\
\hline & & & & (3.208) & & \\
\hline \multirow[t]{2}{*}{ Exports $\cdot$ CIP } & & & & $1.053 * * *$ & $0.875^{* *}$ & $0.990 * *$ \\
\hline & & & & $(0.318)$ & $(0.312)$ & $(0.350)$ \\
\hline \multirow[t]{2}{*}{ Imports · CIP } & & & & $-0.657^{+}$ & -0.631 & $-0.908^{*}$ \\
\hline & & & & $(0.391)$ & $(0.385)$ & $(0.427)$ \\
\hline \multirow[t]{2}{*}{ RP Imports · CIP } & & & & $0.638^{+}$ & 0.518 & 0.574 \\
\hline & & & & $(0.354)$ & $(0.352)$ & $(0.386)$ \\
\hline \multirow{2}{*}{$\begin{array}{l}\text { Imported } \\
\text { inputs · CIP }\end{array}$} & & & & 0.665 & $1.977 *$ & $1.686^{+}$ \\
\hline & & & & $(0.543)$ & $(0.769)$ & $(0.877)$ \\
\hline$R^{2}$ & 0.01 & 0.07 & 0.14 & 0.02 & 0.08 & 0.14 \\
\hline$N$ & 19,392 & 19,392 & 16,848 & 19,392 & 19,392 & 16,848 \\
\hline LRT statistic & $183.9 * * *$ & $139.4 * * *$ & $112.6 * * *$ & $25.3 * * *$ & $22.2 * * *$ & $16.7 * *$ \\
\hline Agreement FE & No & Yes & Yes & No & Yes & Yes \\
\hline Industry FE & No & No & Yes & No & No & Yes \\
\hline \multicolumn{7}{|c|}{ Results with political influence variables } \\
\hline \multirow{2}{*}{$\begin{array}{l}\text { Chair's ideal } \\
\text { point }\end{array}$} & $6.784 * * *$ & & & $6.339 * * *$ & & \\
\hline & $(0.419)$ & & & $(0.686)$ & & \\
\hline \multirow{2}{*}{$\begin{array}{l}\text { Chair's } \\
\text { contributions }\end{array}$} & $1.233 * * *$ & $0.927 * * *$ & $1.221 * * *$ & $1.346^{* * *}$ & $1.031 * * *$ & $1.716^{* * *}$ \\
\hline & $(0.075)$ & $(0.075)$ & $(0.111)$ & $(0.134)$ & $(0.135)$ & $(0.179)$ \\
\hline \multirow{2}{*}{$\begin{array}{l}\text { Chair's } \\
\text { establishments }\end{array}$} & $1.734 * * *$ & $1.901 * * *$ & $1.640 * * *$ & $1.235 * * *$ & $1.457 * * *$ & $2.215^{* * *}$ \\
\hline & $(0.143)$ & $(0.154)$ & $(0.265)$ & $(0.331)$ & $(0.381)$ & $(0.459)$ \\
\hline \multirow[t]{2}{*}{ In Exports } & & & & $0.277 * *$ & $0.338 * * *$ & 0.091 \\
\hline & & & & $(0.104)$ & $(0.102)$ & (0.119) \\
\hline \multirow[t]{2}{*}{ In Imports } & & & & 0.018 & -0.150 & -0.201 \\
\hline & & & & $(0.127)$ & $(0.126)$ & $(0.141)$ \\
\hline \multirow[t]{2}{*}{ In RP Imports } & & & & $0.404 * * *$ & $0.382 * * *$ & 0.236 \\
\hline & & & & $(0.112)$ & $(0.111)$ & $(0.121)$ \\
\hline
\end{tabular}


TA B LE 2 (Continued)

\begin{tabular}{lllllll} 
Model & $\mathbf{1}$ & $\mathbf{2}$ & $\mathbf{3}$ & $\mathbf{4}$ & $\mathbf{5}$ & $\mathbf{6}$ \\
$\begin{array}{l}\text { In Imported } \\
\text { inputs }\end{array}$ & & & $0.582^{* *}$ & 0.342 & $1.046^{* * *}$ \\
$R^{2}$ & 0.02 & 0.08 & 0.20 & 0.02 & 0.08 & $(0.248)$ \\
\hline$N$ & 38,784 & 38,784 & 31,419 & 16,053 & 16,053 & 14,070 \\
\hline Agreement FE & No & Yes & Yes & No & Yes & Yes \\
\hline Industry FE & No & No & Yes & No & No & Yes \\
\hline
\end{tabular}

Notes. Linear probability models with OLS standard errors. The likelihood ratio test is relative to models without trade flow variables for 1-3; and to models without interaction terms for models $4-6$; $* * * p<0.001, * * p<0.01,{ }^{*} p<0.05,+p 0.1$.

of our trade variables with the estimated ideal point of the committee chair governing the hearing. We have transformed this variable so that it ranges from 0 (the most anti-trade chair's ideal point) to 1 (the most pro-trade chair's ideal point). For this reason, the lower order terms on the trade variables represent those variables' correlations with invitations among the most anti-trade committee chairs. For example, the coefficient on $1 n$ Exports is -0.371 indicating that the most anti-trade committee chairs are less likely to invite export-competing industries to testify. Among the most pro-trade chairs, the total effect of $\ln$ Exports is $-0.371+1.053=0.682$, indicating a positive relationship between an industry's exports to a trade partner and its likelihood of being invited to testify. We caution that the variation in committee chairs' ideal points is limited, both because the turnover of chairs is relatively slow over time and because most committee chairs are relatively pro-trade (the median in the data is $0.80)$.

Nonetheless, we see a remarkable congruence between our expectations and the results. Anti-trade committee chairs are generally more likely to invite import-competing industries to testify, and less likely to invite export-competing industries (although these relationships are not significant). On the other hand, pro-trade committee chairs are more likely to invite export-competing industries and industries which source or produce abroad. As an example, an increase in exports from the 25 th to the 75 th percentile is expected to reduce the probability of being invited by $18 \%$ for an anti-trade chair (ideal point $=0.2$ ) and to increase the chance of being invited by $22 \%$ for a pro-trade chair (ideal point $=1) .{ }^{27}$ To examine the impact of these interaction terms collectively, we test the interaction model against a null model which removes only the interaction terms, and find that the null model is always rejected. This provides tentative evidence of our claimed mechanism.

In the lower half of Table 2, we investigate the relationship between measures of industry's political influence and testimony before Congress. For each hearing, we consider both PAC contributions made to the chair and the number of establishments for each industry in the chair's home state. Overall, we find that these variables are consistently positively linked to invitations to testimony. ${ }^{28}$ Invitations to testify are therefore not only about finding pro-trade voices but may also serve as a form of constituent service. The links between the trade flow variables and testimony are generally similar even

\footnotetext{
${ }^{27}$ The confidence interval for the former estimate is very wide $(-105,49)$ and for the latter estimate is quite tight $(14,32)$, reflecting the lack of variation in the chairs' ideal points at the low end.

${ }^{28} \mathrm{We}$ are able to test the most basic model in both services and goods-producing industries, but lose some of our $893 \times 48=42,864$ observations because of missing data on the number of establishments. Note that these variables are highly correlated with industry's contributions to all members of Congress and with industry's total number of establishments in the United States, so it is hard to say whether the specific relationship to the chair, or a greater profile in US politics and the economy more generally, is responsible for these links.
} 
T A B L E 3 Positions of testifiers by type of testimony and organization

\begin{tabular}{|c|c|c|c|c|c|}
\hline & \multicolumn{5}{|c|}{ Position of testifier } \\
\hline & Favor & Insuff. & Oppose & No pos. & Number \\
\hline \multicolumn{6}{|c|}{ Proportion across all groups and types } \\
\hline All testimony & 0.79 & 0.03 & 0.16 & 0.03 & 874 \\
\hline \multicolumn{6}{|c|}{ By majority party in the Chamber } \\
\hline Republican & 0.79 & 0.02 & 0.17 & 0.02 & 744 \\
\hline Democratic & 0.76 & 0.06 & 0.14 & 0.04 & 130 \\
\hline \multicolumn{6}{|c|}{ By trade orientation of committee chair } \\
\hline Pro-trade chair & 0.82 & 0.02 & 0.14 & 0.02 & 722 \\
\hline Anti-trade chair & 0.62 & 0.05 & 0.27 & 0.05 & 152 \\
\hline \multicolumn{6}{|l|}{ By type of testimony } \\
\hline Oral & 0.81 & 0.02 & 0.14 & 0.03 & 437 \\
\hline Submitted & 0.76 & 0.03 & 0.19 & 0.02 & 437 \\
\hline \multicolumn{6}{|l|}{ By type of testifier } \\
\hline Congress & 0.75 & 0.01 & 0.17 & 0.07 & 166 \\
\hline Executive branch & 0.98 & - & 0.02 & - & 53 \\
\hline Producer(s) & 0.87 & 0.04 & 0.08 & 0.01 & 541 \\
\hline Labor union & 0.04 & - & 0.96 & - & 28 \\
\hline NGO or expert & 0.43 & 0.01 & 0.52 & 0.04 & 81 \\
\hline
\end{tabular}

Note. Five additional witnesses do not fall into the types listed above.

when controlling for these political variables, however, suggesting that inviting pro-trade voices is a key concern for chairs.

\section{2 | Support and opposition at Congressional hearings}

Do the invitees to Congressional hearings actually support the trade agreements on which they testify, as our analysis above suggests they should? Table 3 summarizes the expressed positions of witnesses toward the trade agreements on which they are testifying. These positions were coded by hand from a reading of the testimony. Our standard is that an expression must contain clear evidence of a clear position, otherwise the witness is coded as having "no position". We find that $97 \%$ of witnesses do express a clear position. Of these, a very large percentage are in support of the agreement on which they are testifying- $79 \%$ of all witnesses, which rises to $81 \%$ for oral rather than submitted testimony. A further $3 \%$ of all witnesses complain that the agreement does not do enough to liberalize trade, either because the United States' trade partner avoided liberalization in some industry, or because the United States avoided liberalization for some input used by their industry. These demands for more liberalization than embodied in the trade agreement are recorded in the column labeled "Insufficient".

Looking at the testimony by the type of organization, it is clear that producer groups are overwhelmingly in favor of the agreements on which they testify. Opposing producer groups are rare in Congressional hearings. Instead, opposition comes mainly from labor unions and nonproducer interest groups and organizations. These groups form a small percentage of all witnesses-around $12 \%{ }^{29}$

\footnotetext{
${ }^{29}$ Certain members of Congress also express opposition or deep reservations about agreements. These were especially frequent in the hearings on CAFTA-DR.
} 


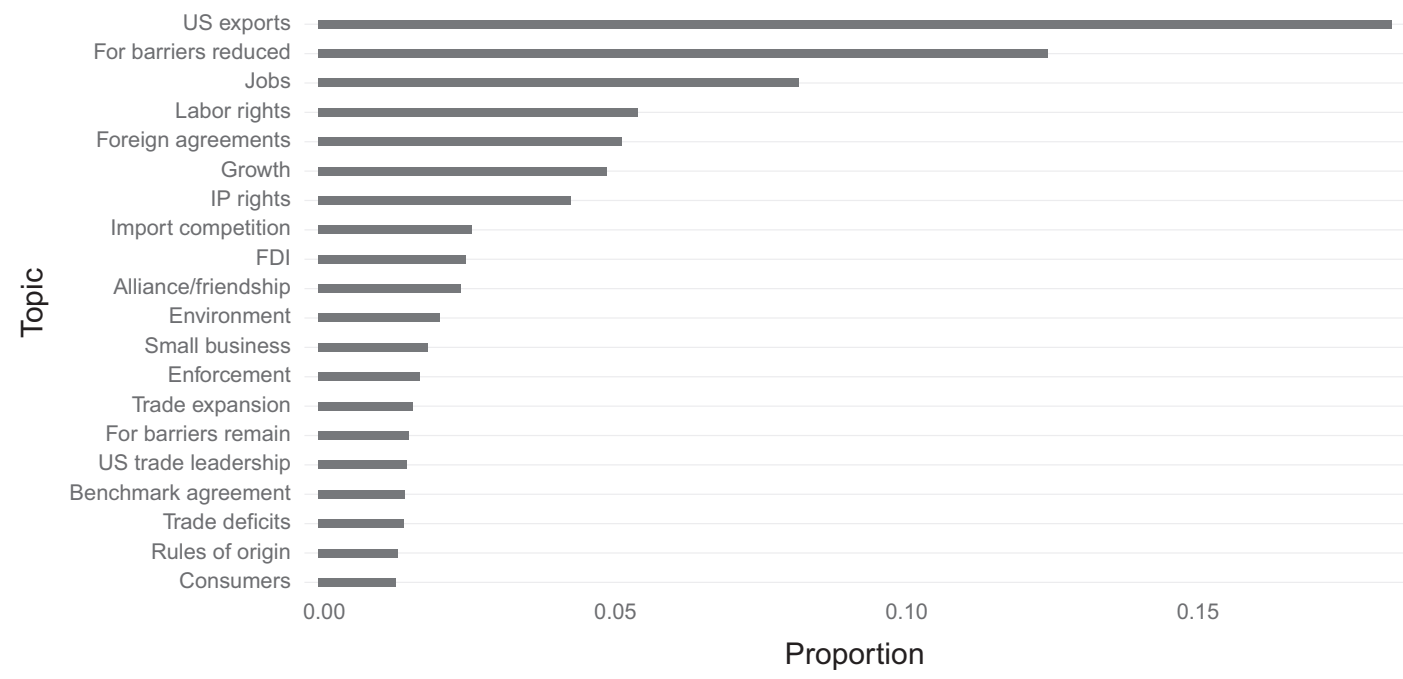

F IG URE 2 Frequency of topics across all testimony

Interpreting the lack of opposition from producers requires some caution. Public opposition to US trade agreements among producers is generally rare, although CAFTA-DR and KORUS did generate some significant opposition from US producers. Many of the US trade agreements are with relatively small trade partners, too, so it might be that the relevant cleavage lies between supporting and indifferent industries, rather than between supporting and opposing industries. That being said, expressions of indifference are relatively rare at hearings too, so at least in this sense hearings are not representative of the interests of US producers.

In the Supporting Information Appendix S2, we consider the adverbs that are used to modify the specific words "support", "favor", "oppose", and "do not support". We find that variations of "support" are mentioned 719 times in the hearings; variations on "oppose" are mentioned only 46 times. The most common modifying adverb is "strongly" in both cases, although in the case of "support", we also see "actively", "fully", "enthusiastically", and "overwhelmingly". We highlight that we do not see "cautiously", "tentatively", "partially”, "weakly", or "mostly". In other words, expressions of support are not nuanced, but rather assertive and without caveats.

Overall, we conclude that US hearings on trade agreements are skewed toward supporters of those agreements in three ways. First, the composition of invited witnesses is biased toward groups (especially producers) that are likely to be supportive of agreements. Second, indifferents to trade are underrepresented in terms of raw numbers. Opponents among producers are scarce in absolute numbers too, although public opposition to US PTAs is rare in any event. Finally, expressions of support are robust and without equivocation. "Strongly supporting" an agreement is so common that it borders on ubiquitous: $31.1 \%$ of all usages of the word "support" in these hearings are preceded by "strongly".

\section{5 | FINDINGS ON TOPICAL CONTENT}

\section{1 | Overall distribution of topics}

We now turn to the topical content of testimony before Congress. Figure 2 summarizes the frequency of the top twenty substantive topics that appear in these testimonies. These topics account for $82.8 \%$ 
T A B L E 4 Modifiers preceding "exports", "jobs", "growth", "imports", and "labor rights"

\begin{tabular}{|c|c|c|c|c|c|c|c|c|c|}
\hline \multicolumn{2}{|l|}{ Export(s) } & \multicolumn{2}{|l|}{$\operatorname{Job}(\mathbf{s})$} & \multicolumn{2}{|l|}{ Econ. growth } & \multicolumn{2}{|l|}{ Import(s) } & \multicolumn{2}{|l|}{ Labor rights } \\
\hline \multicolumn{10}{|c|}{ Preceding verbs } \\
\hline Increase & 119 & Create & 166 & Promote & 52 & Increase & 32 & Recognize & 55 \\
\hline Double & 67 & Generate & 22 & Sustain & 17 & Restrict & 10 & Protect & 29 \\
\hline Expand & 40 & Support & 13 & Foster & 13 & Allow & 9 & Improve & 18 \\
\hline \multirow[t]{2}{*}{ Grow } & 33 & Lose & 9 & Bolster & 12 & Grant & 5 & Strengthen & 6 \\
\hline & & Elimin & 7 & Spur & 11 & Make & 5 & Reinforce & 4 \\
\hline \multicolumn{10}{|c|}{ Preceding adjectives } \\
\hline Good & 168 & New & 97 & Strong & 7 & Additional & 25 & Core & 55 \\
\hline Largest & 141 & Million & 76 & Expected & 6 & Total & 18 & Fundamental & 36 \\
\hline New & 81 & Good & 51 & Greater & 6 & Current & 16 & Basic & 19 \\
\hline Total & 49 & Domestic & 33 & Weak & 6 & Significant & 11 & Existing & 6 \\
\hline Current & 47 & Additional & 28 & Recent & 4 & Partner & 9 & Outstanding & 4 \\
\hline
\end{tabular}

Total uses of word

8,096

2,365

444

2,059

684

Note. Just the word "growth" without "economic" has 1,275 mentions. "Labor rights" also includes mentions of "worker(s') rights".

of all substantive topics across the documents. Notably, "US exports" (discussion of current or future export sales by American firms and industries) was mentioned the most, followed by "Foreign barriers reduced", which refers to reductions of foreign tariff and nontariff barriers that were negotiated as part of the trade agreement. Collectively, discussion of US exports (and how foreign barriers to those exports will be eliminated) accounts for $30.9 \%$ of all substantive discussion, dominating discourse on the content of US trade agreements at Congressional hearings.

Free trade benefits all trading nations due to efficiency gains from arbitrage and specialization in the two-way exchange of goods. It is notable that only one facet of this truism was highlighted in the hearings. Our topic "Trade expansion" (discussion of the current state or expansion of bilateral/multilateral trade as a result of the trade agreement) was not among the 10 most popular. Similarly, import competition is mentioned relatively rarely. The contentious issue of US "trade deficits" just barely enters the 20 most frequently discussed topic codes, and as often as not was mentioned to state that the United States (or some sector) did not have a deficit with the trade partner. If Congressional hearings were a forum of unbiased fact-finding, the content of testimony would cover the benefits and losses from trade across both producers and consumers. Instead, the hearings disproportionately concentrate on positive facets of free trade for producers only.

In order to demonstrate that this discussion of trade is mainly positive in tone, we examine collocations with the nouns "export(s)" and "import(s)" in Table 4. When preceded by a verb, exports are expected to "increase", "double", and "expand". When preceded by an adjective, these exports (or "export markets") are modified in positive ways—_"good", "largest", and "new". ${ }^{30}$ For imports, both increases and restrictions were mentioned, and the frequency of such usage was much less compared to that of exports. Sometimes the use of the word "imports" was combined with "partner"-in other words, the witness is discussing US exports.

\footnotetext{
$\overline{{ }^{30} \text { Note that we eliminate proper nouns and references to specific industries for this analysis. When these nouns are included, the }}$ top two adjectives are "US" and "pork"!
} 
In addition to the sparse discussion of import competition, we highlight a second striking omission: any discussion of offshoring and offshore-outsourcing. For example, foreign direct investment is the 9th most discussed topic at Congressional hearings. That is hardly negligible, but does not seem proportionate to the extreme importance of multinationalization to America's firms. Even more striking, the sourcing of intermediate inputs and final products abroad is only the 31 st most discussed topic. Some of the most important economic gains from globalization come from the construction of global production networks (Baccini et al., 2017). But of course, those networks may imply factory closures and the loss of American jobs-sensitive territory if hearings are designed to persuade skeptical members of Congress responding to an anti-offshoring public (Margalit, 2011; Naoi \& Kume, 2015; Owen, 2017; Owen \& Johnston, 2017).

Jobs, which generally means the creation of jobs in the United States, were the third most discussed topic at trade hearings. The collocation analysis in Table 4 shows the positive gloss placed on this topic. Creation of domestic jobs was emphasized through verbs such as "create", "generate", and "support"; "creating" jobs is mentioned 18 times more often than "losing jobs". Adjectives such as "new", "domestic", and "additional" were also frequently used. Where discussed, job losses were sometimes in reference to losses due to offshoring or imports, but were also discussed to quantify economic losses from delayed implementation of a negotiated trade agreement or from being left out of markets that had negotiated trade agreements with other countries.

Indeed, the discussion of "Foreign agreements" (potential effects of a trade agreement partner's preferential trade agreements with third countries) is the fifth most mentioned topic. In part, this highlights the importance of the "competitive liberalization" dynamic explored in Baccini and Dür (2012), but we also suspect that emphasizing foreign agreements is a rhetorical tactic. If we don't sign this agreement, then European firms are going to steal our markets. We see discussion of the alliance or friendship between the United States and the trade agreement partner as similar, rhetorically, in its reliance on emotion: allies should be rewarded (Mansfield \& Bronson, 1997).

Labor rights are also frequently discussed, but with sensible variation among Congressional hearings by different trading partners (Lechner, 2016). For instance, concerns about labor conditions and their enforcement in Colombia and the Gulf countries were raised repeatedly by Democratic congresspersons and labor unions such as the AFL-CIO (Gray, 2014). ${ }^{31}$ Often, outside experts would express skepticism on the labor rights provisions in the trade agreements, worrying that weak enforcement may lead to unjustifiable trade sanctions against developing country partners. The USTR, pro-trade members of Congress, and producer groups often praised the chapters which "recognize", "protect", "improve", "strengthen", and "reinforce" labor rights. General economic growth was also frequently discussed -6th in our ranking. Trade agreements were positively framed in terms of expected increases in growth. The top verbs relating to growth are "promote", "sustain", "foster", "bolster", and "spur". Adjectives used were also positive if not describing concerns about recent economic slowdowns, which trade agreements were expected to ameliorate.

Intellectual property rights (IPRs) are discussed extensively (7th most overall). Intellectual properties are a key asset for corporate America, and promoting protections for these assets abroad is a key agenda item for IP-intensive industries such as software producers and pharmaceuticals. ${ }^{32}$ IP-intensive industries are also a key force behind US economic growth and national competitiveness. ${ }^{33}$ Given these facts, we therefore interpret the emphasis on intellectual property rights in Congressional

\footnotetext{
${ }^{31}$ On labor rights in trade agreements, see Weiss (2002), Bhagwati and Hudec (1996), Hafner-Burton (2005).

${ }^{32}$ See Shadlen (2004, 2005), Osgood and Feng (2018).

${ }^{33}$ IP-intensive industries accounted for $\$ 6.6$ trillion, or $38.2 \%$ in value added, and directly and indirectly supported 45.5 million jobs, about $30 \%$ of all employment in 2014.
} 
TA B LE 5 SUR model of topical content among goods producers $(N=364)$

\begin{tabular}{lllcc|} 
Topic & Exports & For. barriers & Import comp. & FDI \\
\hline ln Exports & $0.045^{* *}$ & $0.094^{* * *}$ & $-0.072^{* * * *}$ & -0.016 \\
& $(0.015)$ & $(0.026)$ & $(0.011)$ & $(0.010)$ \\
\hline ln Imports & 0.008 & -0.063 & $0.097 * * *$ & -0.032 \\
& $(0.024)$ & $(0.042)$ & $(0.018)$ & $(0.017)$ \\
\hline ln Rel par imports & -0.034 & -0.033 & -0.000 & $0.042^{* *}$ \\
& $(0.019)$ & $(0.034)$ & $(0.015)$ & $(0.014)$ \\
\hline ln Sales & $-0.033^{* * *}$ & 0.004 & $-0.032^{* * *}$ & $0.026^{* *}$ \\
& $(0.009)$ & $(0.016)$ & $(0.007)$ & $(0.007)$ \\
\hline$R^{2}$ & 0.14 & 0.11 & 0.11 & 0.07 \\
\hline
\end{tabular}

Notes. SUR, Seemingly Unrelated Regression

Outcome variables are logged ratios of topic relative to baseline of all other topics. Import competition includes topics on import competition and US reductions of domestic barriers to trade; *** $p<0.001, * * p<0.01,{ }^{*} p<0.05,+p 0.1$.

hearings in the following way. First, it is a truthful reflection of the genuine interests of IP-intensive US firms and industries. Second, although IP provisions in trade agreements have generated enormous controversy from progressive groups, these provisions do not threaten American jobs or growth, and so are highly salable to members of Congress who want globalization without unfortunate distributive consequences within the United States.

\subsection{Are testimonies truthful?}

We now examine the "truthfulness" of testimony in two senses. First, we examine whether the testimony of invited witnesses are responsive to the interests of their industries. Do firms and associations from export-competing industries discuss exports more, and do firms and associations from importcompeting industries discuss imports more? Second, we then examine whether the discussion of these topics is proportionate to the interest stakes. Would a firm from an export-competing industry discuss exports as much as a firm in an equivalently import-competing industry discusses import competition? Are discussions of FDI as responsive to the absolute quantity of related-party imports, as are discussions of exports to the absolute quantity of export flows?

We examine four topics in particular (exports, foreign barriers to be reduced, import competition/ domestic barriers being reduced, and FDI). We use seemingly unrelated regression (SUR) in order to model the dependencies among these topics. Topical proportions must sum to one for any given testimony: to the extent that one topic increases as a share of testimony all other topics must decrease. SUR models this negative dependence among the outcome variables and so improves model precision and is a better description of the data. This approach requires choosing a link function and choosing a baseline category. We use the natural logarithm as our link function, and the summed proportions of all other topics outside of the four mentioned above as our baseline. For example, the DV for the "exports" equation is $\ln$ (Pr. exports)/(Pr. all other topics), where Pr. exports refers to the proportion of a given testimony that was on the topic "exports". Note that the testimony is the unit of analysis and all trade variables are matched to each witnesses' industry.

The results in Table 5 show that testimony is truthful in a relative sense. Firms and associations representing export-competing industries are more likely to discuss exports and reductions in foreign barriers. Firms and corporations from import-competing industries discuss import competition more. 
Likewise, firms from industries with a great deal of related-party imports (our best proxy for verticaltype FDI) are more likely to discuss FDI. Witnesses from producer groups are truthful in the narrow sense that they respond to the features of their own industries.

But are witnesses truthful in an absolute sense? To consider this we use parallel constructions of counterfactual simulations. We first imagine holding the exports of some testifying firm or association's industry at their 75th quantile in their distribution (this is around \$101 million dollars in annual exports). We hold imports at 0 , and all other variables at their median value. We then consider a similar industry, but where exports are held at 0 and imports at $\$ 101$ million dollars. ${ }^{34}$

We find that the percentage of discussion that is devoted to exports is $19.5 \%$ when exports are held at their 75 th percentile. The discussion of foreign barriers to trade being reduced is $20.3 \%$ of the topical content. A highly export-competing industry therefore devotes around $40 \%$ of its testimony to exports and export opportunities (and only $4 \%$ to import competition). A highly import-competing industry devotes $22.2 \%$ of its time to exports and foreign trade barriers, which is in and of itself puzzling, although it may reflect imprecision in the model. Moreover, the percentage of discussion of import competition for such an industry is around $17.7 \%$. Why would $\$ 101$ million in exports elicit copious discussion of export opportunities, but the same amount in imports leads to a much more modest discussion of import competition? Indeed, why would an import-competing industry spend more time discussing exports than import competition?

The discussion of FDI is similar. Increasing a witness' related-party imports from $\$ 0$ to $\$ 101$ million increases the quantity of discussion of FDI (from $6 \%$ to over $10 \%$ ), but this $10 \%$ figure seems somewhat low for a quantity of related-party imports that lies at the variable's 90th percentile. We also reiterate at this point that discussion of the sourcing of intermediate inputs is exceptionally rare in these hearings. Overall, we conclude that Congressional witnesses are responsive to the interests of the sectors or industries that they represent, but only in a relative sense. In absolute terms, discussion of import competition and offshoring are minimized in favor of the aspects of globalization that are more appealing to the general public, like new opportunities to export.

\subsection{Hearings versus submissions to the USTR: The case of KORUS}

In this section, we compare the content of the testimony of firms and associations in Congressional hearings to the content of their public submissions to the USTR. We specifically analyze submissions to the USTR in response to its request for comments concerning KORUS. ${ }^{35}$ We emphasize that the comments were submitted after the agreement was negotiated and signed (although some aspects of the agreement, particularly governing beef and autos, were subsequently renegotiated). These submissions are therefore not fundamentally different in their purpose and timing than the Congressional hearings on the agreement, which also occurred after negotiation.

We make comparisons between the content of Congressional hearings and the content of submissions to the USTR on KORUS because it is one of the most economically significant bilateral trade agreement that the United States has signed to date. Consequently, KORUS had the greatest number of testimonies and submissions among US trade agreements. Also, both Congressional hearings and USTR submissions relating to KORUS had a large number of producers (firms, trade associations, and peak associations) in terms of testifiers and filers.

\footnotetext{
${ }^{34}$ Note that the 25 th percentile for exports equals the 25 th percentile for imports-both are zero. The 75 th percentile for exports equals the 83 rd percentile for imports.

${ }^{35}$ The interagency Trade Policy Staff Committee (TPSC) sought public comment to assist the USTR in its assessment of the free trade agreement between the United States and Republic of Korea signed on June 30, 2007.
} 


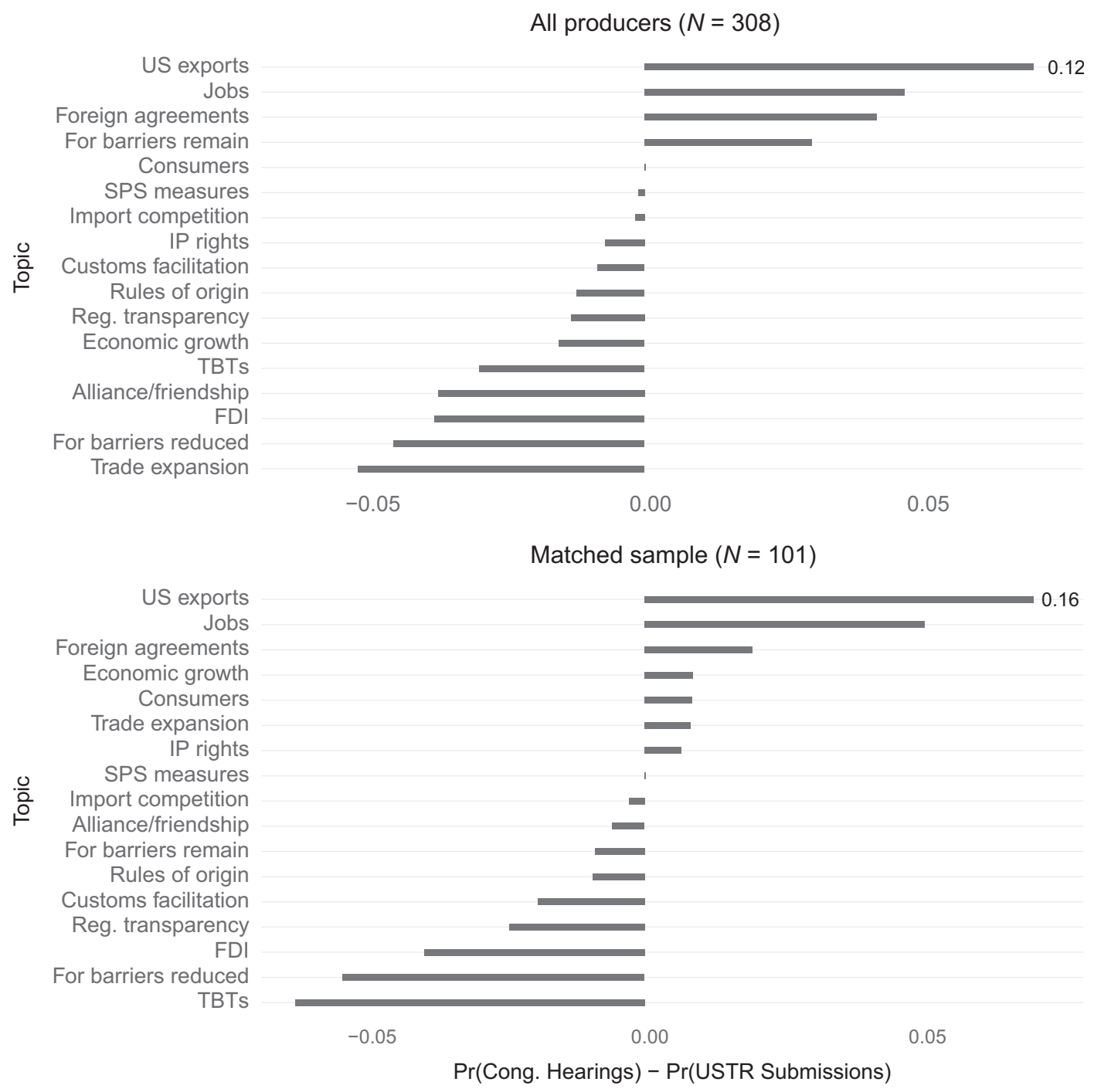

F IG URE 3 Difference in topic frequency between Congressional hearings and submissions to the USTR for Korea-US FTA. All producers refer to all firms and industry associations that either testified in Congress or submitted comments to the USTR (or both). The matched sample is firms and associations that both testified and submitted comments to the USTR, and so represents different emphases for precisely the same actors.

The total number of Congressional testimonies or USTR submissions filed by producers in our combined dataset are 308. This includes 101 testimonies and submissions that were filed by the same corporation or association that used both venues to comment on the KORUS FTA. This matched sample is particularly valuable because it allows us to show that differences in topical emphasis occur for precisely the same actors, and are not merely the result of compositional differences between hearings and submissions. This is useful because Congressional hearings are subject to a stringent review process by committee staff, whereas submissions are open to any interested party wishing to comment. Figure 3 presents the difference in topic frequency between Congressional hearings and submissions to the USTR for the KORUS FTA. The top figure includes all producers while the figure below compares the matched sample for producers that submitted comments to the USTR and also 
testified at Congress. Bars which extend to the right indicate topics which were discussed in greater proportion in Congressional hearings; bars which extend to the left indicate topics that were discussed more in submissions to the USTR.

Among the complete sample in the top half of the figure, we find that producers are much more likely to discuss exports, jobs, and competitive liberalization in Congressional hearings than in USTR submissions. This finding is particularly strong for the exports category, which is enormously overrepresented in Congressional hearing compared to in submissions. This lends support to our findings above, that Congressional hearings overemphasize exports in comparison with other effects of trade agreements.

Foreign direct investment is underrepresented in the Congressional hearings. Producers apparently had significant interests relating to foreign direct investment as shown in their USTR submissions. They simply reduced the discussion of that interest when testifying before Congress. ${ }^{36}$ On the other hand, reductions in foreign trade barriers and bilateral trade flows are also in the top three topics that were covered more frequently in the USTR submissions as opposed to Congressional hearings, which is not expected in a framework emphasizing the propaganda elements of Congressional hearings. The high frequency of "foreign barriers reduced" in the submissions may reflect the USTR's instructions to examine the economic impact of the removal of tariffs and NTBs resulting from the trade agreement. Notably, much of the extended trade agenda such as technical barriers to trade, intellectual property rights, transparency, rules of origin, customs facilitation, and SPS measures are discussed more in the USTR submissions.

Overall, our data show that Congressional hearings on trade agreements play less of a role in information gathering, but provide a venue to promote a winning image of America, and American firms, in a globalizing international economy. In our matched sample, we confirm that our results are not driven by the composition of producers, but by the producers' strategic calculations about the most useful messages across different venues.

\section{6 | DISCUSSION}

While there is some interesting nuance in the evidence, overall our multifaceted investigation points strongly toward a theory of Congressional hearings on trade as pro-globalization propaganda. Wellrounded discussions of globalization's many effects are foregone in favor of a suite of rhetorical techniques designed to create an image of a cost-free globalization. Instead, mercantilist themes of export growth and trade as "competition" abound (Krugman, 1991). Why pursue such a strategy? Our explanation begins with the committee chairs with primary responsibility for putting together the hearings. These chairs have generally been strongly in support of trade agreements, reflecting both major parties' dependence on campaign giving from pro-trade corporate interests. But Congressional voting on trade agreements can be unpredictable: party-line voting is not so regular in this area, and trade is susceptible to mass politicization, as in the recent debate over the TPP. Consequently, chairs put together hearings with two goals in mind. First, to demonstrate that there is strong support from corporate America for these agreements, and so a "no" vote will not be easy for members of Congress relying on corporate campaign giving. Second, to skew the debate on globalization toward its sunnier sides-flooding the chamber's (and perhaps in some small way, the country's) airwaves with discussion of trade's most appealing benefits.

\footnotetext{
${ }^{36}$ Among the relatively small number of cases discussing FDI in Congress, the testimonies focused on the positive returns to the American public and investors rather than describing the potential costs to American workers.
} 
While such an approach may benefit trade agreements in the short run, we also identify costs for the broader project of global economic integration. First, Congressional hearings might lose their ability to persuade if they are viewed as so much propaganda. Indeed, one-dimensional hearings could backfire by making the public cynical about the many genuine benefits of global commerce. A message about globalization's considerable benefits for US consumers, for example, might be more compelling if it came with the acknowledgment that some industries and regions are hurting. Second, policy designed to buffer the harms of globalization may not be correctly identified as needed or explored in sufficient depth. Economic integration has distributive consequences - that is lesson one in the political economy of international economic policy. Simply repeating "Trade Benefits America", as in the name of a new pro-trade coalition, obscures a more complex reality that deserves to be addressed both because it is right, and also to preserve the economic and security benefits of global integration. Finally, and more generally, one-sided Congressional hearings represent a missed opportunity for sound democratic deliberation. Opportunities for reasoned policymaking and persuasion are therefore lost.

\section{ACKNOWLEDGMENTS}

The authors thank Jeffry Frieden, Hye Young You, and Stephen Weymouth, as well as several anonymous reviewers, for many valuable suggestions for the paper.

\section{ORCID}

Iain Osgood (iD http://orcid.org/0000-0002-6084-7102

\section{REFERENCES}

Acharya, R. C. (2015). Trade policy in lobbying equilibrium: With Non-traded and traded final goods and intermediate inputs. Economics \& Politics, 27(2), 313-336. https://doi.org/10.1111/ecpo.12058

Adler, E. S., \& Lapinski, J. S. (1997). Demand-side theory and congressional committee composition: A constituency characteristics approach. American Journal of Political Science, 41(3), 895-918. https://doi.org/10.2307/2111679

Albert, K. W. (2013). An analysis of labor union participation in US congressional hearings. In Sociological Forum, 28 , 574-596. https://doi.org/10.1111/socf.12038

Andrews, K. T., \& Edwards, B. (2004). Advocacy organizations in the US political process. The Annual Review Sociology, 30(1), 479-506. https://doi.org/10.1146/annurev.soc.30.012703.110542

Autor, D. H., Dorn, D., \& Hanson, G. H. (2013). The China syndrome: Local labor market effects of import competition in the United States. The American Economic Review, 103(6), 2121-2168. https://doi.org/10.1257/aer.103.6.2121

Autor, D. H., Dorn, D., \& Hanson, G. H. (2016). The China shock: Learning from labor-market adjustment to large changes in trade. Annual Review of Economics, 8, 205-240. https://doi.org/10.1146/annurev-economics-080315-015041

Baccini, L., \& Dür, A. (2012). The new regionalism and policy interdependence. British Journal of Political Science, 42(1), 57-79. https://doi.org/10.1017/S0007123411000238

Baccini, L., Pinto, P. M., \& Weymouth, S. (2017). The distributional consequences of preferential trade liberalization: Firm-level evidence. International Organization, 71(2), 373-395. https://doi.org/10.1017/S002081831700011X

Baker, A. (2003). Why is trade reform so popular in latin america?: A consumption-based theory of trade policy preferences. World Politics, 55(3), 423-455. https://doi.org/10.1353/wp.2003.0014

Baker, A. (2005). Who wants to globalize? Consumer tastes and labor markets in a theory of trade policy beliefs. American Journal of Political Science, 49(4), 924-938. https://doi.org/10.1111/j.1540-5907.2005.00164.x

Bhagwati, J. N., \& Hudec, R. E. (1996). Fair trade and harmonization: Prerequisites for free trade? Vol. 2. Cambridge, MA: MIT Press.

Blanchard, E., \& Matschke, X. (2015). US multinationals and preferential market access. Review of Economics and Statistics, 97(4), 839-854. https://doi.org/10.1162/REST_a_00496 
Bombardini, M., \& Trebbi, F. (2012). Competition and political organization: Together or alone in lobbying for trade policy? Journal of International Economics, 87(1), 18-26. https://doi.org/10.1016/j.jinteco.2011.11.011

Burstein, P., \& Hirsh, C. E. (2007). Interest organizations, information, and policy innovation in the US Congress. Sociological forum, 22(2), 174-199.

Chamberlain, J. P. (1936). Legislative processes: National and state. New York, NY: D. Appleton-Century Company, Incorporated.

Chase, K. A. (2009). Trading blocs: States, firms, and regions in the World Economy. Ann Arbor, MI: University of Michigan Press.

Chinn, M. D., \& Frieden, J. A. (2011). Lost decades: The making of America's debt crisis and the long recovery. New York, NY: WW Norton \& Company.

Diermeier, D., \& Feddersen, T. J. (2000). Information and congressional hearings. American Journal of Political Science, 44(1), 51-65. https://doi.org/10.2307/2669292

Esterling, K. M. (2011). Deliberative disagreement in US Health Policy Committee Hearings. Legislative Studies Quarterly, 36(2), 169-198. https://doi.org/10.1111/j.1939-9162.2011.00010.x

Gawande, K., Krishna, P., \& Olarreaga, M. (2012). Lobbying competition over trade policy. International Economic Review, 53(1), 115-132. https://doi.org/10.1111/j.1468-2354.2011.00673.x

Gilligan, T. W., \& Krehbiel, K. (1987). Collective decisionmaking and standing committees: An informational rationale for restrictive amendment procedures. Journal of Law, Economics, \& Organization, 3(2), 287-335.

Goldstein, J. (1988). Ideas, institutions, and American trade policy. International Organization, 42(1), 179-217. https:// doi.org/10.1017/S0020818300007177

Gowa, J., \& Mansfield, E. D. (1993). Power politics and international trade. American Political Science Review, 87(2), 408-420. https://doi.org/10.2307/2939050

Gray, J. (2014). Domestic capacity and the implementation gap in regional trade agreements. Comparative Political Studies, 47(1), 55-84. https://doi.org/10.1177/0010414013488535

Gutmann, A., \& Thompson, D. F. (1998). Democracy and disagreement. Cambridge, MA: Harvard University Press.

Hafner-Burton, E. M. (2005). Trading human rights: How preferential trade agreements influence government repression. International Organization, 59(3), 593-629.

Hiscox, M. J. (2002). International trade and political conflict: Commerce, coalitions, and mobility. Princeton, NJ: Princeton University Press.

Huitt, R. K. (1954). The congressional committee: A case study. American Political Science Review, 48(2), 340-365. https://doi.org/10.2307/1951200

Irwin, D. A. (1998). From Smoot-Hawley to reciprocal trade agreements: Changing the course of US Trade Policy in the 1930s. In M. D. Bordo, C. Goldin, \& E. N. White (Eds.), The defining moment: The great depression and the American Economy in the twentieth century (pp. 325-352). Chicago: University of Chicago Press.

Jensen, J. B., Quinn, D. P., \& Weymouth, S. (2015). The influence of firm global supply chains and foreign currency undervaluations on US trade disputes. International Organization, 69(4), 913-947. https://doi.org/10.1017/ S0020818315000247

Jensen, J. B., Quinn, D. P., \& Weymouth, S. (2017). Winners and losers in international trade: The effects on US presidential voting. International Organization, 71(3), 1-35.

Johns, L., \& Wellhausen, R. L. (2016). Under one roof: Supply chains and the protection of foreign investment. American Political Science Review, 110(1), 31-51. https://doi.org/10.1017/S000305541500057X

Kim, I. S. (2017). Political cleavages within industry: Firm-level lobbying for trade liberalization. American Political Science Review, 111(1), 1-20. https://doi.org/10.1017/S0003055416000654

Kim, I. S., Milner, H. V., Bernauer, T., Spilker, G., Osgood, I., \& Tingley, D. (2016). Firms' Preferences over Multidimensional Trade Policies: Global Production Chains, Investment Protection and Dispute Settlement Mechanisms. In PEIO Conference (January 12-14, 2017). Bern.

Kim, I. S., \& Osgood, I. (2019). Firms in trade and trade politics. Annual Review of Political Science, 22, (Forthcoming). Krehbiel, K. (1990). Are congressional committees composed of preference outliers? American Political Science Review, 84(1), 149-163. https://doi.org/10.2307/1963634

Krikorian, G. P., \& Szymkowiak, D. M. (2007). Intellectual property rights in the making: The evolution of intellectual property provisions in US free trade agreements and access to medicine. The Journal of World Intellectual Property, 10(5), 388-418. https://doi.org/10.1111/j.1747-1796.2007.00328.x 
Krugman, P. (1991). The Move Toward Free Trade Zones, in Policy Implication of trade and Currency Zones. In Symposium sponsored by the FRB of Kansas City.

Lechner, L. (2016). The domestic battle over the design of non-trade issues in preferential trade agreements. Review of International Political Economy, 23(5), 840-871. https://doi.org/10.1080/09692290.2016.1231130

Leyden, K. M. (1995). Interest group resources and testimony at congressional hearings. Legislative Studies Quarterly, 20(3), 431-439. https://doi.org/10.2307/440230

Madeira, M. A. (2016). New trade, new politics: Intra-industry trade and domestic political coalitions. Review of International Political Economy, 23(4), 677-711. https://doi.org/10.1080/09692290.2016.1218354

Manger, M. S. (2009). Investing in protection: The politics of preferential trade agreements between North and South. Cambridge, UK: Cambridge University Press. https://doi.org/10.1017/CBO9780511635311

Manger, M. S. (2012). Vertical trade specialization and the formation of North-South PTAs. World Politics, 64(4), 622-658. https://doi.org/10.1017/S0043887112000172

Mansfield, E. D., \& Bronson, R. (1997). Alliances, preferential trading arrangements, and international trade. American Political Science Review, 91(1), 94-107. https://doi.org/10.2307/2952261

Mansfield,E. D., Milner, H. V., \& Rosendorff, B. P. (2002). Why democracies cooperate more: Electoral control and international trade agreements. International Organization, 56(3), 477-513. https://doi.org/10.1162/002081802760199863

Mansfield, E. D., \& Mutz, D. C. (2009). Support for free trade: Self-interest, sociotropic politics, and out-group anxiety. International Organization, 63(3), 425-457. https://doi.org/10.1017/S0020818309090158

Margalit, Y. (2011). Costly jobs: Trade-related layoffs, government compensation, and voting in US elections. American Political Science Review, 105(1), 166-188. https://doi.org/10.1017/S000305541000050X

Martin, A. D., Quinn, K. M., \& Park, J. H. (2011). MCMC pack: Markov chain Monte Carlo in R. Journal of Statistical Software, 42(9), 1-21.

McGrath, R. J. (2013). Congressional oversight hearings and policy control. Legislative Studies Quarterly, 38(3), 349376. https://doi.org/10.1111/1sq.12018

Milner, H. (1987). Resisting the protectionist temptation: Industry and the making of trade policy in France and the United States during the 1970s. International Organization, 41(4), 639-665. https://doi.org/10.1017/S0020818300027636

Milner, H. V. (1988). Resisting protectionism: Global industries and the politics of international trade. Princeton, NJ: Princeton University Press.

Naoi, M., \& Kume, I. (2015). Workers or consumers? A survey experiment on the duality of Citizens' interests in the politics of trade. Comparative Political Studies, 48(10), 1293-1317. https://doi.org/10.1177/0010414015574879

O’Halloran, S. (1994). Politics, process, and American trade policy. Ann Arbor, MI: University of Michigan Press. https://doi.org/10.3998/mpub.14032

Oleszek, W. J. (2014). Congressional procedures and the policy process. Thousand Oaks, CA: Sage.

Osgood, I. (2016). Differentiated products, divided industries: Firm preferences over trade liberalization. Economics \& Politics, 28(2), 161-180. https://doi.org/10.1111/ecpo.12075

Osgood, I. (2017a). The breakdown of industrial opposition to trade: Firms, product variety, and reciprocal liberalization. World Politics, 69(1), 184-231. https://doi.org/10.1017/S0043887116000174

Osgood, I. (2017b). Industrial fragmentation over trade: The role of variation in global engagement. International studies quarterly, 61(3), 642-659. https://doi.org/10.1093/isq/sqx027

Osgood, I. (2018). Globalizing the supply chain: Firm and industrial support for US trade agreements. International Organization, 72(2), 455-484. https://doi.org/10.1017/S002081831800005X

Osgood, I., \& Feng, Y. (2018). Intellectual property provisions and support for US trade agreements. The Review of International Organizations, 13(3), 421-455. https://doi.org/10.1007/s11558-017-9279-y

Owen, E. (2017). Exposure to Off shoring and the politics of trade liberalization: Debate and votes on free trade agreements in the US house of representatives, 2001-2006. International Studies Quarterly, 61(2), 297-311. https://doi. org/10.1093/isq/sqx020

Owen, E., \& Johnston, N. (2017). Occupation and the political economy of trade: Job routineness, off shorability and protectionist sentiment. International Organization, 71(4), 665-699. https://doi.org/10.1017/S0020818317000339

Pierce, J. R., \& Schott, P. K. (2016). The surprisingly swift decline of US manufacturing employment. The American Economic Review, 106(7), 1632-1662. https://doi.org/10.1257/aer.20131578

Rho, S., \& Tomz, M. (2017). Why don't trade preferences reflect economic self-interest? International Organization, 71(S1), S85-S108. https://doi.org/10.1017/S0020818316000394 
Sachs, R. C. (2003). Hearings in the US senate: A guide for preparation and procedure. Washington, DC: Library of Congress, Congressional Research Service.

Sachs, R. C. (2004). Hearings in the house of representatives: A guide for preparation and procedure. Washington, DC: Library of Congress, Congressional Research Service.

Sachs, J. D., Shatz, H. J., Deardorff, A., \& Hall, R. E. (1994). Trade and jobs in US manufacturing. Brookings Papers on Economic Activity, 1994(1), 1-84. https://doi.org/10.2307/2534630

Schattschneider, E. E. (1935). Politics, pressures and the tariff. New York, NY: Prentice-Hall, Inc.

Scheve, K. F., \& Slaughter, M. J. (2001). Labor market competition and individual preferences over immigration policy. The Review of Economics and Statistics, 83(1), 133-145. https://doi.org/10.1162/003465301750160108

Shadlen, K. C. (2004). Patents and pills, power and procedure: The North-South Politics of Public Health in the WTO. Studies in Comparative International Development (SCID), 39(3), 76-108. https://doi.org/10.1007/BF02686283

Shadlen, K. C. (2005). Exchanging development for market access? Deep integration and industrial policy under multilateral and regional-bilateral trade agreements. Review of International Political Economy, 12(5), 750-775. https:// doi.org/10.1080/09692290500339685

Shepsle, K. A. (1986). Institutional equilibrium and equilibrium institutions. In H. Weinberg (Ed.), Political science: The science of politics. Herbert weinberg (pp. 51-81). New York, NY: Agathon.

Shepsle, K. A., \& Weingast, B. R. (1987). The institutional foundations of committee power. American Political Science Review, 81(1), 85-104. https://doi.org/10.2307/1960780

Truman, D. B. (1971). The governmental process. New York, NY: Alfred A. Knopf.

Weiss, M. S. (2002). Two steps forward, one step back-or vice versa: Labor rights under free trade agreements from Nafta, through Jordan, via Chile, to Latin America, and beyond. USFL Review, 37(3), 689.

\section{SUPPORTING INFORMATION}

Additional supporting information may be found online in the Supporting Information section at the end of the article.

How to cite this article: Lee J, Osgood I. Exports, jobs, growth! Congressional hearings on US trade agreements. Econ Polit. 2019;31:1-26. https://doi.org/10.1111/ecpo.12121 